Биљана С. Ристић

Универзитет у Београду

Филолошки факултет

Катедра за српски језик са

јужнословенским језицима
УДК 821.163.41-14.08 Обреновић М. https://doi.org/10.18485/uzdanica.2020.17.1.9

Оригинални научни рад Примљен: 28. фебруар 2020.

Прихваћен: 1. јун 2020.

\title{
КАКО ЈЕ ЛУТАО КНЕЗ - СТИЛСКА АНАЛИЗА ПЕСМЕ „СВЕТСКИ ПУТНИК” КНЕЗА МИХАИЛА ОБРЕНОВИЋА ${ }^{1}$
}

$A \bar{u} c \bar{u} p a \kappa \bar{u}$ : Предмет овог рада је лингвостилистичка анализа песме „Светски путник”, за коју се сматра да ју је написао српски кнез Михаило Обреновић. Штампана је 7. ептембра 1844. године у Сербском народном листу без навођења имена аутора. Песма се састоји из десет катрена и у дијалошкој је форми. Након приказа релевантне литературе и досадашњих истраживања, песму смо лингвостилистички анализирали узевши у обзир време и околности у којима је дело настало.

Кључне речи: „Светски путник”, кнез Михаило, Михаило Обреновић, песма, анализа.

\section{УВОДНЕ НАПОМЕНЕ}

Песма „Светски путник” кнеза Михаила Обреновића штампана је на првој страници Сербског народног листа 7. септембра 1844. године (36. число). Име аутора том приликом није наведено. У фусноти, на истој страни Сербског народног листа стоји: „Ово бы се могло ГГ. Вучићу и Авраму посветити?”. Није наведено на ког се ГГ. Вучића и Аврама напис односи, али можемо претпоставити да је реч о Томи Вучићу Перишићу и Авраму Петронијевићу, који су, поред Јеврема Обреновића, чинили Намесништво које је владало Србијом уместо малолетног кнеза Михаила. Такође, Тома Вучић Перишић предводио је буну којом је кнез Михаило свргнут 1842. године. Кнез се након тога повукао из земље заједно са неколико стотина Срба. Путовао је и живео по Европи, а са једног од путовања, 1844. године, настала је песма „Светски путник”.

${ }^{1}$ Рад је настао у оквиру пројекта број 178006: „Српски језик и његови ресурси: теорија, опис и примене” који финансира Министарство просвете, науке и технолошког развоја Републике Србије. 
Поред тога што је био државник, кнез Михаило је имао и поетских склоности, а своје афинитете је отелотворио у три сачуване песме. Додуше, постоје индиције да је кнез имао још поетских покушаја, мање или више успешних, али је уобичајено да се за његово име везују три песме: „Молитва кнеза српског Михаила на брегу морском”, „Светски путник” и „Што се боре мисли моје”. Последња наведена, за коју постоји и музичка композиција, најпознатије је поетско дело кнеза Михаила.

О песми „Светски путник” није много писано, сем дискусија о потенцијалном ауторству. Правопис је карактеристичан. Ако узмемо у обзир да је година када је песма настала и објављена 1844, дакле пре званичне победе Вуковог језика и правописа, ова песма добија још више на значају, те, поред поетичке, има и важну историјскојезичку компоненту, па можемо рећи да је својеврсни споменик за проучаваоце језика.

Циљ. Анализу правописних решења овде нећемо вршити, него ћемо покушати да дамо детаљну тематско-семантичку и лингвостилистичку анализу песме и да истакнемо сва она језичка онеобичајења која у функцији диференцирања стила стоје у поетском темељу песме, а важно питање којим се руководимо јесте шта је то што је differentia specifica језика ове песме која дозвољава да се дело прихвати као уметничко, те има и такав значај, поред културно-историјског.

Досадашња истраживања и преглед релевантне литературе. Ђорђе Перић је 1992. године објавио у Прилозима за књижевносй, језик, истиорију и болклор рад насловљен као „Заборављене песме кнеза Михаила Обреновића у нашим рукописним штампаним изворима". Поред поменуте три песме, Перић (1992: 97) тврди да је кнез аутор и текста једног епитафа посвећеног грчком јунаку Димитрију Чамису Каратасу. Поред тога што констатује да је кнез Михаило аутор „Светског путника”, Перић наводи и текст песме, прилагођен данашњој правописној норми. Ако изузмемо правописна решења, текст је истоветан овоме који ми у даљем тексту доносимо, а који смо преузели из Сербског народног листа. Сем песме кнеза Михаила Обреновића, у средишту Перићеве (1992: 87-97) пажње су и две песме истог наслова из тог доба, чији је аутор Коста Богдановић ${ }^{2}$, а затим и песма „Отпьвъ”, коју је написао непознати аутор, присталица Карађорђевића.

Васо Милинчевић у свом тексту „Поетски покушаји кнеза Михаила

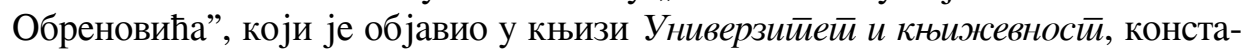
тује да је „после свргавања са власти 1842. године, кнез Михаило живео у емиграцији, претежно у Бечу”. Затим, „у то време испољио је афинитет према књижевности и књижевницима, такође и према музици" (Милинчевић 2013:

${ }^{2}$ Богдановић, иначе обреновићевац, свог „Светског путника” је написао као одговор на кнежеву песму и објавио у истом листу, а непознати аутор (највероватније Атанасије Николић), карађорђевићевац, својом песмом је одговорио Богдановићевим стиховима и, посредно, кнезу Михаилу Обреновићу (Перић 1992: 87-97). 
219). У даљем тексту аутор (2013: 219-220) наводи како је у Бечу тада живео и кнез Милош, који је одржавао пријатељске односе са Вуком Караџићем, па је, по његовој жељи, Вук био „саветник и духовни васпитач” кнеза Михаила, те су њих двојица заједно путовали и једном боравили на обали Северног мора. „На том путовању испеване су (или записане) и две кнежеве песме [...] Испод наслова песме 'Светски путник' са стране је стављено: 'У Дрезди [Дрездену] 10. јулија 1844', а управо наслов друге песме ${ }^{3}$ упућује да је испевана на обали Северног мора.”

Марија Клеут и Мирјана Стефановић у својој Дойуни библиотрафији срииских рукойисних йесмарица из 1984. године наводе да песма постоји у следећим песмарицама: 1. Песмарица Петра Лончара Вукова (1850), бр. 11, сигн. М 517, почиње стихом: Стан', путниче, тко си ти; 2. Песмарица Бранка Сандића (1853), бр. 91, сигн. М 564, почиње стихом: Стан, путниче, тко си ти; 3. Песмарица Стефбана и Василија Николајевића (1860), бр. 105, сигн. М 11.113, почиње стихом: Стан', путниче, тко си ти; 4. Песмарица М. Д. Дејановића (после 1871), бр. 126, сигн. М 417, почиње стихом: Стан', путниче, тко си ти (Клеут, Стефановић 1984: 139-164). Постојање ових песмарица потврђује и Перић (1992: 87).

Милева Алимпић у књизи Живот и рад генерала Ранка Алимпића из 1892. помиње да је кнез Михаило „кад је био на брегу Јадранскога мора ${ }^{4}$, написао своју 'Молитву' и 'Светског путника”' (Алимпић 1892: 227).

\section{ВРЕМЕ И МЕСТО НАСТАНКА И ОБЈАВЉИВАҢА ПЕСМЕ}

Према подацима које имамо, песма је, што смо већ напоменули, први пут објављена 7. септембра 1844. године у Сербском народном листу.

Документ који се састоји од дволиста, где је на једној страни штампана песма „Молитва княза србскогъ Михаила на брегу морскомъ”, а на другој страни песма „Светски путник” (са податком испод наслова: „у Дрезди 10. юния"), чува се на Одељењу реткости Универзитетске библиотеке у Београду под сигнатуром P 1895. Нема података када је и где штампан, а обе песме су украшене по једним цртежом.

У Даници или Календару за преступну 1864. годину објављен је текст ове песме на другој и трећој страни, уз навођење већ познатог податка: „у Дрезди 10. юния".

Песма постоји и у рукописним песмарицама које смо навели у претходном делу рада. Све су настале после 1844 . године.

\footnotetext{
${ }^{3}$ Мисли се на песму „Молитва кнеза српског Михаила на брегу морском”.

${ }^{4}$ Приметимо овде да се тврдња Милеве Алимпић да је песма настала док је кнез био на Јадранском мору (1892: 227) не слаже са Милинчевићевим помињањем Северног мора (2013: 219).
} 
Ни у једном од ових извора уз песму није наведено име аутора.

Издање из Дрездена од 10. јуна 1844. нисмо нашли, као ни претходни истраживачи (Перић и Милинчевић), а немамо информација ни да је стварно постојало. Наиме, поменути податак о времену и месту који се често наводи испод наслова песме може се односити на настанак песме, а не нужно и прво издање.

\section{ТЕКСТ ПЕСМЕ}

Текст песме преносимо из Сербског народног листа ${ }^{5}$, а он одговара тексту у осталим изворима.

\section{СВЕТСКІИ ПУТНИКЪ}

1.

Стан’ Путниче! Тко си тьл,

Имашъ кога оть рода?

Ели жива іошть Мати,

Тако дичногъ порода?

2.

Србскогъ я самъ порекла,

Народъ цео мой е родъ;

Майка ми е умрла,

Но жив ми е іоште Богъ.

3.

Куд’ путуешъ тако младъ,

Гони л' тебе неволя?

Был' се вратіо дома радъ?

Ништо с' лица увела.

4.

Безпредпланъ путь е мой,

Тражимъ Судбе кончину;

Дома имамъ, ніе мой,

Зато лицемъ увену.

5.

Имашь кога са собомъ,

Да m' олагча путнъій труд?

И да л’оста за тобомъ

Вюрнылй коій дома друг?

6.

Богъ и чувство Србина, Са мномъ ранне путуе, Добры Срба множина Мени присон ревнуе.

7.

Не мой тужит' Србине,

К’о са гране узбранъ плодъ;

Са обратомъ Судбине,

Одржа һе тебе родъ.

8.

Док' узживимъ было где, Самъ һу себи Србъ быти;

Но кадъ умремъ по Судби,

Гробъ тко һе ми залити?!

9.

Земля твоя гди лежи, Кое с' быо Господар', На Листу ми сбележи, И дай мени то на даръ.

10.

Што я немамь то недамь Земль нисамь Господаръ;

Едно срдие я имамъ,

Omъ cыроте то е даръ.

57. септембар 1844. године (36. число). 


\section{МЕТРИКА}

Ова песма има 40 стихова, изострофична је и структурисана у десет катрена. Сви катрени су изометрични, чине их седмерци, сем трећег где је изометричност нарушена трећим стихом који је осмерац (Был' се вратіо дома padъ?), те је то случај хиперкаталексе. Рима је у свим строфама укрштена (абаб), а у осмој строфи је нарушена јер се где и Судби не подудара ни у ком звучном аспекту. Доминира мушка (нетачна) рима, а нема правилности у јављању женске риме. Начелно, цезура је после четвртог слога. Нарочитој звучној изражајности доприносе и одређене фоностилеме, посебно апокопа. Изостављање гласова аутор бележи апострофом (Куд', Бbыл', Стан'...). Поред самог звучног ефекта, овакав поступак је у служби успостављања изометричности стихова. Почетно слово сваког стиха је велико, а о употреби великог слова у другим позицијама говорићемо у делу који следи.

\section{СТИЛСКА РЕШЕЊА И ТЕМАТСКА СТРУКТУРА ПЕСМЕ}

Песма је у дијалошкој форми. Непарни катрени представљају обраћање песничком субјекту, а парни његов одговор. Могуће је и да песнички субјекат разговор води са самим собом. Перић (1992: 90) истиче да је песма „тужни, меланхолични унутрашњи дијалог прогоњеног кнеза ${ }^{6}$ са својом отаџбином".

1. Прва строфа има отварачку улогу. Почиње екскламативним тоном и дозивањем путника којем се обраћа. Иако, рекосмо, правописна решења нису предмет овог рада, морамо да истакнемо значај употребе великог слова. Формално неименовани глас се обраћа песничком субјекту и ословљава га са Путниче (Стан' Путниче! Тко си тыл...). Овај вокатив је обележен почетним великим словом. Занимљиво је то да је заменица $m b l$, која се односи на исти денотат, написана малим словом. Ако погледамо целу песму, велика почетна слова су код следећих речи: Путниче, Мати, Богъ, Судбе, Србина, Срба, Србине, Судбине, Србъ, Судби, Господаръ, Листу. Манир којим се песник руководи је да се ентитети који се изузетно поштују означе великим почетним словом (Мати, Судбина...), поред и данас утврђеног начела о употреби великог слова код имена народа и народности, божанстава и слично (Србин, Бог...). Зашто је П у Путниче велико? Не заборавимо то да строфа о којој је реч представља обраћање неименованом „путнику”, као и чињеницу да је заменица у наглашеном облику mы написана малим словом, а односе се на

${ }^{6}$ Година када је песма објављена, а вероватно и настала, јесте 1844 , а то је време између две владавине кнеза Михаила, када је он био у емиграцији. Отуда Перићев израз „прогоњени кнез”.

${ }^{7}$ Овде изузимамо речи на почетку стиха где је слово увек велико. 
исти ентитет. Значи ли то да писац, који је истовремено и песнички субјекат, ако узмемо у обзир да је песма аутобиографска, подразумева да га намерник мора изузетно поштовати (с обзиром на то да је он (бивши) владар), онако како се поштују остали побројани ентитети? Ова тврдња не чини се много вероватном ако се сетимо малог $m$ у заменици $m b l$. Или је реч о истицању носиоца теме целе песме? Индикативно је и то да је „путникова мати” тако дичногъ порода, што иде у прилог величању.

2. Садржај друге строфе су одговори на питања постављена у првој. Ту се путник национално самоодређује и износи патриотско-популистичку тврдњу да је цео народ његов род.

Хипербатон ${ }^{8}$ у првом стиху другог катрена и стављање придева Србскогъ у иницијалну позицију има посебан значај у светлу фокализације. Ако томе додамо и да је синтагма Србскогъ порекла разбијена сегментом я самъ, јасно је да је аутору ово одређење изузетно важно. Ово свакако није једини хипербатон у песми, има их још, али је први који лирски субјекат употребљава у одговору на питање, а хипербатонско онеобичавање има, поред фокализацијског и комуникативног, и стилогени ефекат.

У истој строфи имамо помињање најважнијих ентитета за једног српског кнеза (србскогъ (порекла), народъ, майка, Богъ). Поред националног одређења путника, ова строфа нас информише да је путник верујућа особа. Наиме, иако се питање из прве строфе односи на његову мајку, путник, поред одговора да није жива, сам нуди информацију да му је жив іоште Богъ. Овде сазнајемо и о систему вредности код путника и положају мајке у њему. Наиме, овај питањем неизазвани одговор показује да су мајка, која га је донела на свет, и Бог, који га је створио, асоцијативно, али и вредносно повезани. Овде се нећемо упуштати у нагађања који од ова два појма има већу вредност код путника.

3. У интерогацијском духу наставља се трећи катрен. Већ смо поменули хиперкаталексу у стиху Был' се вратіо дома радъ?. Суштински, овај стих је од велике важности за целу песму. Субјекат лута, историјски збачен са власти, послат из земље - светски путник. Ако узмемо целу песму у обзир, позитиван одговор на питање се сам намеће, а оно постаје ништа до - реторичко.

Важна улога ове строфе у целој песми је да направи места за оно што у наставку песме предстоји, а то је интимна исповест путника која је базирана на одговору на два питања која су управо овде постављена: Куд’ путуeшъ, које пружа места за просторно одређење, и Гони л’ тебе неволя?, што контекстуализује даље саопштавање о узроцима лутања и алудира на узроке кнежеве емиграције из Србије.

${ }^{8}$ Хипербатон се односи на „разбијање синтагматски уско повезаних компонената неком компонентом којој ту у уобичајеном реду речи није место” (Ковачевић 1998: 31). 
4. Боравак у туђој земљи и лутање експлицитно се потенцира у четвртој строфи и стиху Дома имамъ, ніе мой. Стих је контрастно структурисан, субјекат има нешто што није његово. Дом који има, а није његов, овде се може односити и на Србију, одакле је кнез Михаило свргнут са власти 1842 , а може се односити и на сва места где је боравио од тада па до настанка песме. Други део стиха, ніе мой, иде у прилог и једном и другом тврђењу.

Анастрофа9 ${ }^{9}$ Судбе кончину, где је неконгруентни атрибут пребачен у препозицију, има улогу у наглашавању фокуса, али је и остварење мелодијске структуре и риме где кончину долази на крај стиха и римује се са увену, а остварује се и паралелизам присутан у још неким строфама, на шта ћемо понаособ указати.

Последњи стих ове строфе је потврда информације из претходне строфе о увелом лицу као последици лутања, чега је и сам субјекат свестан.

5. Ако смо у претходној строфи видели да је путник невесео и да му је тешко, у петој видимо да глас који са путником разговара има саосећања са мукама кроз које овај пролази. Наиме, свестан је да је пут тежак и да је потребно да га неко олагча.

У овој строфи имамо два локуса - овде, на месту разговора, и тамо, у Србији. Онај ко се води са собом и који је ту да олагча путнъій труд супротстављен је оном који је остао за тобом (путником) и чија је пожељна особина верност.

6. Приказивање родољубивих осећања, истакнутих у другој, наставља се у шестој строфи. Путник се узда у Божју помоћ док је ван своје земље, прати га и чувство Србина.

Анастрофа у стиху Добры Срба множина остварена је премештањем неконгруентног атрибута у препозицију и има улогу јачег наглашавања, али и остваривања паралелизама на начин већ поменут.

7. Саосећање које неименовани глас испољава у петој строфи, односно својој претходној реплици, постоји и у седмој строфи, али се овде јавља дух оптимизма. Наиме, он верује да ће се судбина обрнути ${ }^{10}$, те да ће путника онда одржати род.

Занимљиво је поређење у овој строфи где је светски путник - К’o са гране узбранъ плодъ, а поредбени оператор ко доприноси већој кохезији и смисаоној еквивалентности. Речи плодъ и родъ, које се римују, имају занимљив однос. Наиме родъ, поред тога што се надовезује на поменуто поређење, те се тиме односи на путника, односи се и на српски народ.

${ }^{9}$ Анастрофа се односи на „измјену мјеста двију компонената које у општеупотребној конструкцији по правилу слиједе једна за другом” (Ковачевић 1998: 30).

${ }^{10} 1844$. године Србијом је владао Александар Карађорђевић. Уколико би се субдина обрнула, као што їлас поручује, то би значило (као што се и стварно у будућности десило) повратак Обреновића на власт. 
8. Опозиција живот и смрт боји осећања субјекта у осмој строфи. Упитни оператор тко није на почетку него је у средини, а испред њега је именица гробъ. Медијална позиција оператора доноси јаче наглашавање његовог значења, али и укрштање са стихом Самъ һy себи Србъ бьлти, где је оператор $c a м$ на почетку реченице и смисаоно стоји наспрам тко. Ако узмемо у обзир поменуто да у другој и шестој строфи путник исказује, поред родољубивих, религиозна осећања, онда је ова строфа судбином везана са четвртом где се тражи Судбе кончина. На овом месту, пак, субјекат Судбу везује за умирање, а поређење ове две конотације упућује на то да је за путника крај, било тренутних трагања и лутања, било живота - судбински.

9. Ова строфа ствара простор за проширену смисаону раван која ће своје максимално простирање остварити тек у последњој строфи. Сегмент Земля твоя који стоји на почетку стиха омогућава да глагол лежи дође на крај стиха и да се римује са обележи, али и омогућава значењско подвлачење. Такође, ако је путнику инхерентно својство да путује, а овде видимо да земља лежи, значи ли то и супротстављеност Србије као константе и њеног владара који није сталан?

10. Последњи катрен има затварачку улогу за целу песму, али успоставља и јаку корелативну везу са претходном строфом. Негација (немамъ, нисамь) овде се тиче описа стања и припадности одређених ентитета путни$\kappa y$. Облик недамъ директно одговара захтеву исказаном у деветој строфи и одбијање је да се он изврши.

Прва два стиха су реченице са предикатима у одричном облику, при чему анастрофа у другом стиху корелира и са првим стихом, али јаче са претходном строфом. Први и трећи стих су, дакле, опонирани антонимном употребом глагола немамъ-имамъ, а све у функцији посебног истицања објеката. Аутор затвара песму римом Господаръ -даръ, која у парним стиховима постоји и у претходној строфи.

Песник у емиграцији пише песму о свом лутању, телесном и духовном, и жељи да се врати у Србију. Песму боји тренутним расположењем и религијским и родољубивим осећањима. Иако јавности не толико позната, песма заслужује своје место како због важности тренутка у коме је настала, тако и због књижевно-језичких елемената који су од изузетне важности, а не треба занемарити ни то да се сматра да јој је аутор некадашњи кнез Србије.

\section{ЗАКЉУЧАК}

У раду смо анализирали песму „Светски путник”. Ауторски се приписује кнезу Михаилу Обреновићу. Према подацима којима располажемо, најстарије штампано издање је оно из 1844. године, када је 7. септембра песма објављена у Сербском народном листу. Чини је десет катрена. Рекли 
смо да је, због језика и правописа, ова песма важан историјски споменик. Унутартекстовни микродискурс и кореспонденција са стањем песниковог духа у изгнанству и туђини има посебан афективни нагласак, те лингвостилистичка анализа мора узети у обзир време и околности у којима је дело настало. Хармонија стилематичног и стилогеног плана је у поједином случајевима нарушена, али то нарушавање нема наружујући ефекат, чак и усамљено изневеравање изометричности које руши начело еквивалентности не треба узети за зло.

\section{ИЗВОРИ}

Даница или Календар за преступну годину 1864 са различитим песмама / скупіо и издао Георгіє Стаићъ, Изслуженьй Словослагатель Правителствене Типографіє, Београд: Штампарија Николе Стефановића, 2-3.

Песмарица Бранка Сандића (1853), бр. 91, сигн. М 564, Рукописно одељење Матице српске.

Песмарица М. Д. Дејановића (после 1871), бр. 126, сигн. М 417, Рукописно одељење Матице српске.

Песмарица Петра Лончара Вукова (1850) бр. 11, сигн. М 517, Рукописно одељење Матице српске.

Песмарица Стеббана и Василија Николајевића (1860), бр. 105, сигн. М 11.113, Рукописно одељење Матице српске.

Светскій путникъ, Сигн. Т Р 1895. Одељење реткости Универзитетске библиотеке у Београду (нема података о аутору, издавачу, години и месту издања).

Светскій путникъ (1844), Сербски народни лист, XXXVI (Будим), 281 (нема података о аутору).

\section{ЛИТЕРАТУРА}

Алимпић (1892): Милева Алимпић, Живот и рад генерала Ранка Алимпића (у свези са догађајима из најновије српске историје), Београд: Српска краљевска државна штампарија.

Клеут, Стефановић (1984): Марија Клеут, Мирјана Стефановић, Допуна библиографији српских рукописних песмарица, Зборник Матице српске за славистику, 26, Нови Сад: Матица српска, 139-164.

Ковачевић (1998): Милош Ковачевић, Стилске фбиуре и књижевни текст, Београд: Требник.

Милинчевић (2013): Васо Милинчевић, Универзитет и књижевност, Београд: Филолошки факултет Универзитета у Београду.

Перић (1992): Ђорђе Перић, Заборављене песме кнеза Михаила Обреновића у нашим рукописним штампаним изворима, Прилози за књижевност, језик, историју и фолклор, LV-LVI, Београд: Филолошки факултет у Београду, 84-99. 
Biljana S. Ristić

University of Belgrade

Faculty of Philology

Department for Serbian with South-Slavonic Languages

\section{HOW THE PRINCE WANDERED - PRINCE MIHAILO OBRENOVIĆ'S POEM "WORLD TRAVELLER"}

Summary: This paper deals with the poem "World Traveller" which is considered to be written by Serbian prince Mihailo Obrenović. It was printed on the 7th of September 1844 in the Serbian national Gazette without specifying the author's name. The poem consists of ten quatrains in a dialogical form. The first part of the paper offers a review of relevant literature and previous studies on the topic, while the second part represents a linguo-stylistic analysis of the poem, taking into account the epoch and the circumstances in which it was written.

Keywords: "World traveler", prince Mihailo, Mihailo Obrenović, poem, analysis. 